Saudi Journal of Business and Management Studies Abbreviated Key Title: Saudi J Bus Manag Stud ISSN 2415-6663 (Print) IISSN 2415-6671 (Online) Scholars Middle East Publishers, Dubai, United Arab Emirates Journal homepage: http://scholarsmepub.com/sjbms/

Original Research Article

\title{
Empowering the Uneducated Youths in Nigeria through Small and Meduim Scale Enterprises in Enugu State, Nigeria
}

\author{
P. C. Okonkwo, Ph.D, C. N. Onyeze, Ph.D, D. I. OCHIAKA, Ph.D
}

Department of Co-Operatives and Rural Development, Enugu State University of Science and Technology, Enugu, Enugu State, Nigeria

DOI: $10.36348 /$ sjbms.2019.v04i09.011 ～| Received: 21.09.2019 | Accepted: 28.09.2019 | Published: 30.09 .2019

*Corresponding author: P. C. Okonkwo

Abstract

The general aim of this research work is to examine "the ways of empowering the uneducated youths in Nigeria through Small and Medium Scale Enterprise: A Study of Ezeagu Local Government Area, Enugu State". The specific objectives of this research work include the following: to identify the number of SME formed by uneducated youths in Ezeagu LGA, to examine the roles of small and medium scale enterprises in youth empowerment in Enugu State.For a successful completion of this research work, the researcher made use of both primary and secondary methods of data collection for information gathering. The population of the study was 1308 while the sample size of 306 was gotten through Taro Yamene formula. The data collected were presented in tables and analyzed with simple percentage while the hypotheses stated were tested with chi square. The findings made includes: the roles of small and medium scale enterprises in youth empowerment in Enugu State are entrepreneurship promotion, provision of employment opportunities, mobilization of savings and financial resources for productive enterprise activitiesand equitable growth across regions and between men and women, the contributions of government in SME development are provision of infrastructural development, promotion of small and medium scale enterprises through its policies, provision of capital and loans to small and medium scale business owners andprovision of skill acquisition centers in diverse areas.In conclusion, capital formation has affected the role of small and medium scale enterprises in youth empowerment in Enugu State to a very great extent, the challenges militating against the efforts of small and medium scale enterprises in youth empowerment in Enugu State are financial problems, management problems, infrastructure problems and socio cultural problems. The researcher therefore recommends that government at all levels in Nigeria should be encouraged to float Microfinance institutions in order to enable SMEs access enough funds for their businesses. This will enable the poor in their areas to have access to credit without which our strive for financial inclusion and poverty eradication will not be realized, the central Bank of Nigeria (CBN) should hasten up its proposal to introduce financial literacy in school's curriculum. The ability of SMEs to keep appropriate and up to date records are what banks require for extension of their credits to individuals and groups.

Keywords: Empowering, Uneducated Youths, Small And Meduim Scale Enterprise.

Copyright @ 2019: This is an open-access article distributed under the terms of the Creative Commons Attribution license which permits unrestricted use, distribution, and reproduction in any medium for non-commercial use (NonCommercial, or CC-BY-NC) provided the original author and source are credited.

\section{INTRODUCTION}

\section{Background of the Study}

Nigeria is a developing economy with 83.5 percent of her population falling into the youth age bracket of $18-40$ years Adenikinju [1]. Besides, women constitute about half of the population of Nigeria. Any plan to develop the Nigerian economy must consider very seriously youth development. There are more reasons to the centrality of youths in development process than just their population. The multiplier effect of human investment in youths is greater than the effect of comparable investment in aged members of the population. Akpan and Ekong [2] is of the view that human capital development of youths, in the forms of investment in youth education and health, has been proved to be socially more effective in 
generating higher benefit than comparable investments in the aged population.

Youth, as noted by Ekong [3], bears the genes for economic and biological development and sustenance of a society. It is the youth who constitute the most productive workers in any economy. Youths are adventurous, venturesome, enterprising and inventive.

Notwithstanding the strategic developmental roles that the youths are supposed to be playing in a country or part thereof, these components of the Nigerian population are besieged by a number of problems which constrain their attainment of optimal contribution to wealth creation and economic growth.

Few youths own economic capital and even fewer of them engage in modern businesses as entrepreneurs. Although youths are very actively engaging in economic activities, they are mostly busy in the micro- and small-scale informal business spectrum, grappling with crude technology, underemployment, low productivity and low income returns that can hardly attain their basic needs. They earn less income and the share of the GDP appropriated to the youth population is lower [4].

The youth also face economic problems and constraints which are considerably comparable to those besetting the women. Youth are contending with outright unemployment and disguised unemployment. This is partly as a result of lack of education or inadequacy of education as well as inadequate jobcreation capacity of the economy. Youth also lack means of production both at the micro-scale as financial capital and more so at large-scale outlays such as manufacturing plants and other modern business outfits. It is based on this issues that this project is been designed to study evaluate empowering the uneducated youths in Nigeria through small and medium enterprises.

\section{Statement of the Problem}

The small and medium scale Industries survey conducted in 2005 by the central Bank of Nigeria (CBN) provides some evidence that apart from the acute short of technology, managerial skills, poor management, adverse environment, and change in policy, capital is a source of great concern to the entrepreneur in the sector especially among the enterprising youths.

In a country where finance is a major constraint on development, the problem confronting the private sector in Nigeria above all small and medium scales Industries standout.

Most large scale industries in Nigeria have reduced their borrowings due to high interest rates and the short term nature of available loans. At the same time, banks are unwilling to lend to the small and medium scale sector with its high perceived risks. In this case, lending is not efficient to the real sector and loanable funds are currently used to finance primary consumer imports and exports foreign exchange markets. These factors have enormously affected the roles of small and medium scale enterprises in youth empowerment in Nigeria. This study therefore will address the problems militating against small and medium scale enterprises in empowering the uneducated youths. Such problems include;

Inadequate infrastructural facilities,

Inadequate capital,

Lack of technical know how

Poor management

\section{Objectives of the Study}

The broad objective of this study is to appraise the concept of empowering the uneducated youths in Nigeria through small and medium scale enterprises focusing on a study of Ezeagu Local Government Area of Enugu State. The specific objectives include the following;

1. To identify the number of SME formed by uneducated youths in Ezeagu LGA.

2. To examine the roles of small and medium scale enterprises in youth empowerment in Enugu State.

\section{Research Questions}

The following questions are stated for this study;

1. How many SME are formed by the uneducated youths in Ezeagu LGA?

2. What are the roles of small and medium scale enterprises in youth empowerment in Enugu State?

\section{Research Hypotheses}

Hypothesis One

$\mathrm{H}_{\mathrm{O}}$ : Small and medium scale enterprises do not play significant roles in youth empowerment in Enugu State.

$\mathrm{H}_{\mathrm{I}}$ : Small and medium scale enterprises play significant roles in youth empowerment in Enugu State.

Hypothesis Two

$\mathrm{H}_{\mathrm{O}}$ : Capital has not affected the role of small and medium scale enterprises in youth empowerment in Enugu State.

$\mathrm{H}_{\mathrm{I}}$ : Capital has affected the role of small and medium scale enterprises in youth empowerment in Enugu State.

\section{REVIEW OF RELEVANT LITERATURE Conceptual Framework of the Study}

Nigeria remains a country with very high potential but an equally high inertia to develop. The country is blessed with abundant supply of enormous 
human, agricultural, petroleum, gas, and large untapped solid mineral resources Ubon [5]. Since her independence from British rule in 1960, the country has gone through decades of political instability and this has brought with it a climate of social tension and an unpredictable market for business. The successive forceful takeover of government by the use of military coup and the indigenization policy of the late 70's has put off investors who hitherto saw the country as a large and growing market. Due to the nature of these governments, there is perceived corruption, policy instability, poor infrastructural development and lack of accountability of public funds Adeyemi and Badamus [6]. For these reasons, the World Bank described Nigeria as a paradox World Bank [7]. This is also true for most Sub-Saharan African countries as industrial production has declined or stagnated over the past decades.

According to Hassan [8], since its independence, the Nigerian government has been spending an immense amount of money obtained from external funding institutions for entrepreneurial and small business development programs, which have generally yielded poor results. Unfortunately these funds hardly reach the desired business because they may be lost to bureaucratic bottle necks and end up in accounts of public office holders. Despite these setbacks, the role of small business owned by middle class Nigerians, set up by individual savings, gifts and loans and sometimes sustained by profit cannot be ignored. According to Ike [9], countries that have made economic breakthroughs in the last two decades demonstrated beyond doubt that the development of entrepreneurship has been the sine qua non of economic growth and development. According to Inegbenobor [10], the significant role SMEs play in development is acknowledged world over. He noted that in developed countries such as the USA, where big corporations are dominant, SMEs still play enormous role in the country's economy.

Also, according to Jimodu [11] SMEs occupy an important and strategic place in economic growth and equitable development in all countries. Constituting as high as $90 \%$ of enterprises in most countries worldwide, SMEs are the driving force behind a large number of innovations and contribute to the growth of the national economy through employment creation, investments and exports. Owing to the success of the Asian tigers, interest is running high globally particularly in developing countries that are in the rat race to meet up and reduce the economic and development gap. Chinese and foreign experts estimated that SMEs are now responsible for about $60 \%$ of China's industrial output and employ about $75 \%$ of the workforce in China's cities and towns Kayode [12]. These SMEs creates jobs for workers who have been laid off from state-owned enterprises due to the steady transition from communism to a market based economy.

A 2004 survey conducted by the Manufacturers Association of Nigeria (MAN) revealed that only about ten percent $(10 \%)$ of industries run by its members are fully operational Olagunju [13]. Essentially, this means that 90 percent of the industries are either ailing or have closed down. Given the fact that manufacturing industries are well-known catalysts for real growth and development of any nation, this reality clearly portends a great danger for the Nigerian economy. Adoyi and Agbo [14] attributed the cause of this sorry state to such factors as poor infrastructure, multiple taxes imposed on manufacturers in Nigeria by all tiers of government and the difficulty in accessing finance. He noted, "The debris of dilapidated manufacturing concerns across the country is the outcome of years of harsh operating conditions". Basil [15], also remarked, "in addition to policy somersault, funding remains a challenge to all stakeholders in the manufacturing sector, the several palliatives, including the Small and Medium Industries Equity Investment Scheme (SMIEIS) and other sector-specific incentives notwithstanding". He added, "In summary, 30 percent of industries in Nigeria have closed down. About 60 percent are ailing companies and only 10 percent operate at sustainable level". Ekezie [16] emphasized that low capacity utilization has undermined the competitiveness of manufacturing industries, whose fortunes have been worsened by the impact of globalization. He recalled that at Nigeria's independence in 1960, the manufacturing sector's contribution to national Gross Domestic Product (GDP) was 3.8 percent and that despite the discovery of oil, manufacturing contributed as much as 9.9 percent to the GDP from 1975 to 1981 when capacity building was above 70 percent. He however regretted that the story is different today as the manufacturing sector is back at the independence level as it contributed a mere 4.7 percent to GDP in 2013 while industrial capacity utilization dropped to a paltry 48.8 percent in 2013 .

The above is indeed not encouraging as it is representative of the fate of the manufacturing subsector of the SMEs. It was said that the large manufacturing companies are even better off given that those of them, which have international affiliation do get succor and support from their parent companies or technical partners overseas. The support and services the multinationals get from their parent companies could be driven by the profit repatriation, expansion of their overseas market and other motivations but overall, the Nigerian economy benefits if only through employment generation. 


\section{Intervention of Small and Medium Scale Enterprises on Poverty Alleviation and Employment Generation in Nigeria}

Poverty and unemployment has been a major problem for most developing countries across the world. Poverty as a multifarious phenomenon has plagued the world in general and Nigeria in particular over the years. It is often described as a condition wherein people are unable to satisfy their basic needs of food, clothing, and shelter Inegbenobor [10]. In a fairly broad perspective, poverty is characterized by deprivation, social inferiority, isolation, physical weakness, vulnerability (high risk and low capacity to cope), powerlessness and humiliation Jimodu [11]. In Nigeria, the most obvious dimension of poverty is low and highly variables level of income and consumption. Income levels are low in Nigeria. Despite the modification version of national minimum wage, only $7 \%$ of the population benefits directly. This is as a result of majority of Nigerian citizens (70-75\%) depends on subsistence agriculture Kayode [12]. Other reflecting variables of poverty in Nigeria are increase in illness, geographical isolation as a result of bad road network and political disempowerment. Consequently, high level of poverty in the country has forced an increasing number of the citizen into informal trading/commercial activities, handcraft, and retail shops eateries and commercial motorcycling operators.

On the other hand, the widespread problem of unemployment created by the inability of working age people to secure a job has greatly overwhelmed Nigerian economy. In a recent report at the 3rd SouthEast Regional Integration programme in Enugu which focuses on Micro-SMEs addressing the problem of unemployment in the State, the State Governor promised to give support to the growth of Small and Medium Scale Enterprises (SMEs) in the State in order to fight and banish poverty and unemployment Olagunju [13]. Furthermore, he stated that SMEs played significant role in economic development, form the backbone of the private sector and account for about $60 \%$ of employment across the world. Therefore the agenda focusing on SMEs is one of the vehicles for attaining global competitiveness by the State. Some of the interventions of the Government in enhancing SMEs in Enugu State towards poverty reduction and employment generations include:

- Inauguration of 23-man State Council on Micro, Small and Medium Enterprises to coordinate the activities of SMEs in the state;

- Partnership with the Central Bank of Nigeria in its efforts to inject N220 billion low interest long term development finance for the benefits of SMEs;

- Partnership with the Bank of Industry and Bank of Agriculture is also exclusively proSMEs;

- Appropriation of N300million for private sector development aimed at providing soft loans to SMEs as well as facilitate capacity building opportunities for operators on the rudiments of doing sustainable business and

- Establishment of Cooperatives Board with a mandate to organize all cooperative societies in Enugu State and to regulate their activities in the area of accessing loan;

Also in Nigeria, the Federal Government has also employed a number of efforts, some of which were economic driven, for examples, establishment of microfinance banks, small and medium scale enterprises, among others to reverse or abate poverty in the country. At various times since the 1970s, the government has designed and introduced measures to promote SMEs in order to support employment generation thereby reducing poverty among the citizens Ubon [5]. These efforts are geared towards enhancing the operation of small scale businesses. Also, these measures have included fiscal monetary, and export incentives. The fiscal incentives included tax holidays and tariff concession. In terms of monetary support, the Central Bank of Nigeria introduced credit guidelines requiring commercial and merchant banks to allocate a portion of their loanable funds to small businesses. Several developmental financial institutions and schemes were also established to aid small businesses, including the Nigerian bank of commerce and industry (NCBI), the Nigerian Industrial Development Bank (NIDB), and the World Bank SMEI and SMEII initiatives Adeyemi and Badamus [6]. There were also export initiatives from the Nigerian Export-Import bank (NEXIM) to stimulate export loan facilities to small businesses as well as export duty exemptions administered by the Nigeria Export Promotion Council (NEPC).

Other small business incentive programs included personnel training, repair and maintenance of specialized machines, and extension services. Small business assistance programs have also been established by local and state governments. Adoyi and Agbo [14], is of the view that over the past six years, the government has pursued a policy that should provide fertile ground for investment. It has been noted that, with the round for small-business including trade liberalization and making the operating environment more friendly to entrepreneurs. The International Monetary Fund (IMF) has agreed to support more economic growth in Nigeria by helping to finance infrastructure improvements Basil [15]. Therefore, promotion of such enterprises in developing economies like Nigeria is of paramount importance since it brings about a great distribution of income and wealth, economic self dependence, entrepreneurial development, employment and a host of other positive, economic uplifting factors [16]. 
Government Policies on Small and Medium Scale Growth and Development in Nigeria

Ikherehon [17], mentioned various schemes that have contributed to the growth of Small and Medium Scale Enterprises in Nigeria. The industries credit scheme (ICS) was introduced in 1971 as a revolving grant by the federal and state governments in Nigeria to assist in meeting the credit needs of SMEs on a relatively more liberal condition than in private leading institutions.

\section{The Nigeria Bank for commence and industry (NBCI).}

The Nigeria Bank for commence and Industry was established jointly by the federal government of Nigeria and the Central bank of Nigeria (CBN) in 1978 as the apex institution for financing Small and Medium Scale Enterprises. The rationale for establishing the bank was to bring financial discipline to bear and to hopefully ensure a more efficient utilization of scarce financial resources for the development of viable Small and Medium Scale Enterprises [18].

\section{World Bank facilities for Small and Medium Scale Enterprises:}

In order to further promote the growth of Small and Medium Scale Enterprises in Nigeria the federal government of Nigeria also negotiated additional financial assistance from the World Bank to complement other sources of funds available to small and medium scale Enterprises [19].

This resulted into a loan of $\$ 270$ million which was managed directly by Small and Medium Scale Enterprises apex unit within the Central Bank.

Also the establishment and recapitalization of Micro Finance Banks further eased the provision of funds for Small and Medium Scale Enterprises particularly in villages. Objectives for which micro finance banks scheme was established include the following according to [20].

- To enhance service delivery by micro finance institutions to Micro, Small and Medium Scale Enterprises (MSMEs).

- To make financial services accessible to a large segment of potentially productive Nigerians which otherwise would have little or no access to financial services.

- To promote linkage programmes between universal banks specialized in financial institutions and micro finance banks.

- To reduce unemployment and increase social mobility.

- To enhance the implementation of the national economic empowerment and development strategy (NEEDs).

Before the full take-off of micro finance institutions Entrepreneurs of Small and Medium Scale
Enterprises did not have easy access to formal financial institutions to raise capital and it was on that note that Akingunola [21], stated that one of the major hindrances to Small and Medium Scale Enterprises' development in Nigeria is finance. Micro finance is therefore primarily adopted as a means to overcome the acute problem of finance faced by Small and Medium Scale Enterprises.

\section{Operation Feed the Nation (OFN)}

This programme was introduced by General Olusegu Obasanjo in 1976 following the chronic inability of the agricultural sector of the economy to satisfy the food need of the nation. The programme was able to create awareness on self-reliance in food production among the Nigerian people.

\section{National Directorate of Employment (NDE)}

The directorate was established by decree on the 24th October, 1986 and it commenced full operation in January 1987 with the primary aim of promoting skill acquisition, self employment and labour intensive work scheme. The scheme was targeted at school leavers, apprentice, graduates etc. The programme was to address four (4) major areas as itemized below [22]:

- Small Scale Enterprises programme

- Vocational skill development programme

- Rural employment promotion programme

- Special public work programme

\section{The Family Support Programme (FSP)}

This programme was set up by late General Sani Abacha in 1993 alongside Family Economic Advancement Programme (FEAP). Both programmes were aimed at granting soft loan or credit to the Nigerian families to enable them engage in small scale businesses that will enhance their living standard.

\section{The national poverty eradication programme (NAPEP)}

Safiriyu and Njogo [23], explained that before the introduction of National Poverty Eradication Programme (NAPEP), a temporary poverty Alteration Programme in year 2000 was put in place to cushion the effect of terrible economic hardship faced by large number of unemployed people in the country. The intent was to provide monthly stipends to 200,000 unemployed people across the country so that they could start up small businesses and be self reliant. The programme was to be structured to benefit three categories of people namely:

- $\quad$ Skilled unemployed

- Unskilled and semi-skilled unemployed

- Unskilled and uneducated

The skilled unemployed people were provided with a micro-credit to enable them established and viable venture. The second category were trained for a period of 3-12 months or attached to a relevant construction and manufacturing companies for a period 
of 2 years to enable them acquire additional skills after which they will be provided with micro credit to enable start-up a businesses of their own. The third and final category were to either acquire formal education through Universal Basic Education (UBE) or be provided with permanent menial jobs in the areas of agriculture, road maintenance, tree planting etc.

It was reported by World Bank [7] that the National Poverty Eradication Programme (NAPEP) was designed to eradicate poverty absolutely among Nigerians through strategies that provide for the participation of all registered political parties, traditional rulers and community leaders.

\section{The Youth Empowerment Scheme (YES)}

This scheme was exclusively designed to empower youths economically and it consist of three (3) programmes as follows:

- Capacity Acquisition Programmme (CAP)

- Mandatory attachment Programme (MAP) and

- Credit Delivery Programme (CDP)

The Capacity Acquisition Programme (CAP) is to enable participants acquire skills and vocational capabilities while Mandatory Attachment programme (MAP) is to assist graduates who have completed their mandatory National Youth Service Corps (NYSC) and who are yet to secure full-time employment [8]. The Credit Delivery Programme (CDP) on the other hand is to provide micro-credit empowerment scheme and was to achieve the following objectives:

- National Employment Rate 3\%

- Graduate self-employment rate $50 \%$

- Non-graduate self-employment rate $60 \%$

- Skill acquisition rate for school leavers $60 \%$

- Establishment of local resources-based college industries per local government area, five (5) units per year.

- Annual growth rate replacement of traditional methods of production with improved technology in agricultural sector $15 \%$

- Annual growth rate of development of relevant technologies $15 \%$

\section{National Economic Reconstruction Fund (NERFUND)}

Sequel to the introduction of structural Adjustment programme (SAP) in 1986 and the subsequent devaluation of currency, coupled with sharp rise in interest rate, many small and medium scale Enterprises found it difficult to obtain loan to finance their investment [9]. To bridge the gap, the federal government in 1990 set up the National Economic Reconstruction Fund to provide relatively long-term loans (5-10 years) to small and medium scale Enterprises at a very low interest rate.
Small and Medium Scale Enterprises Development Agency of Nigeria (SMEDAN)

Inegbenobor [10] explained that the Small and Medium s Enterprises Development Agency of Nigeria was established by the SMEDAN Act of 2003 to promote the development of Micro, Small and Medium Scale Enterprises (MSMEs) sector of the Nigerian economy. The agency position itself as a one-stop shop for MSMEs and Development. According to Kayode [12] the Agency has industrial development centers in twenty two (22) states of the federation which include, Bauchi, Ogun, Lagos, Sokoto, Niger, Edo, Ondo, Kano, Abuja, Katsina, Enugu, Oyo, Yola, Jos, Ogoja, Rivers, Kwara, Kaduna, Osun, Borno, Benue and Imo states respectively. According to Jimodu [11] new opportunities abound for film makers as the Nigerian Film Corporation (NFC) in partnership with SMEDAN organized a maiden training programme in the city of Kano which began on the 17th of October, 2011.

\section{Small and Medium Industries Equity Investment Scheme (SMIEIS)}

Inegbenobor [10], opined that the SMIEIS is the latest of the schemes designed to tackle the problems of financing Small and Medium Industries in Nigeria which requires all banks to reserve 10 percent of their pre-tax profit for equity investment in SMEs. SMIEIS which is the recent development in SMEs financing was initiated by bankers committee of Nigerian Banks and was approved on the 21st December, 1999. According to the bankers committee, SMIEIS was a response to the then president Obasanjo's concern and policy measure for promoting Small and Medium Scale Enterprises as a vehicle for rapid industrialization. In ensuring strict compliance with the objectives of SMIES, Ike [9], reported that the central Bank of Nigeria has thrown a debt of about N4.5 billion into accounts of Banks that have failed to invest their funds set aside for SMIEIS. Despite this stringent measure by the Central Bank, Hassan [8], still argued that financial institutions have not been able to address the gap in terms of credit, savings and other financial services required by Small and Medium Scale Enterprises in Nigeria.

\section{Challenges of Small and Medium Scale Enterprises in Nigeria}

Despite the catalytic role of SMEs in the economic emancipation of countries, some of their major operational challenges in Nigeria Include:

\section{Financial Problems}

About $80 \%$ of Small and medium enterprises are stifled because of poor financing and other associated problems [7]. The problem of financing SMEs is not so much the sources of funds but its accessibility. Factors identified inhibiting funds accessibility are the stringent conditions set by financial institutions, lack of adequate collateral and credit information and cost of accessing funds Sanusi [22]. 
Safiriyu, and Njogo [23], believes that the capital shortage problem in the small firm sector is partly one, which stems for the uneconomic deployment of available resources by the owner-managers. This view was shared by Akingunola [21], who claimed to have seen businessmen take loans for expansion projects only to turnaround to marry new wives, acquire chieftaincy titles or buy houses abroad. Izedomi [20], in a study of SMEs in Nigeria observed that financing working capital needs was the most frequently mentioned problem. Iromaka [19], expressed the view that the funding problem of SMEs is primarily due to the behavior of banks and imperfection of the capital markets.

\section{Management Problems}

Lack of trained manpower and management skills also constitute a major challenge to the survival of SMEs in Nigeria. According to Ireghan [18], 90\% of all these business failures result from lack of experience and competence. Ikherehon [17], also added that inefficiency in overall business management and poor record keeping is also a major feature of most SMEs; technical problems/competence and lack of essential and required expertise in production, procurement, maintenance, marketing and finances have always led to funds misapplication, wrong and costly decision making.

\section{Inadequate Basic Infrastructure}

Government has not done enough to create the best conducive environment for the striving of SMEs, the problem of infrastructures ranges from shortage of water supply, inadequate transport systems, lack of electricity to improper solid waste management. Nigeria's underdeveloped physical and social infrastructures create a binding constraint to SMEs growth, since; they heavily rely on the inefficiently provided state infrastructures and cannot afford the cost of developing alternatives.

\section{Socio-Cultural Problems}

Most Nigerian Entrepreneurs do not have the investment culture of ploughing back profits. Ekezie [16], stressed that the attitude of a typical Nigerian entrepreneur is to invest today and reap tomorrow. Also, the socio-political ambitions of some entrepreneurs may lead to the diversion of valuable funds and energy from business to social waste. The problem of bias against made in Nigeria goods is significant. Most Nigerians have developed a high propensity for the consumption of foreign goods as against their locally made substitutes.

\section{Strategic Planning Problems}

SMEs often do not carry out proper strategic planning in their operations. Basil [15], stated that one problem of SMEs is lack of strategic planning. Sound planning is a necessary input to a sound decisionmaking.

\section{Location/Economic Problems}

Market stores are dominated by absentee landlords who charge exorbitant rates. The ownership of market stores by politicians is crowding real smallscale operators out of the market. The high rents charged by store owners on good locations have forced real small-scale operators into the streets or at best into accessible places. Also, domestic economic problems of deregulation and removal of protection as well as the global financial crisis have been detrimental to SMEs.

\section{Poor Accounting System}

The accounting system of most SMEs lack standards hence, no proper assessment of their performances. This creates opportunity for mismanagement and eventually leads to the downfall of the establishment.

\section{Multiple Taxations}

This has become a major problem especially given the role of tax consultants and agents hired by local governments. They are often crude in their operation, excessive in their assessment and destructive in their relationship with the production process. They tax everything in their bid to generate revenue without considering the net effect to household incomes and employment.

\section{Unstable Policy Environment}

Instability in government policies have caused some SMEs to collapse. One of such policies is that of the 1980s when government specified that cocoa should not be exported in raw or unprocessed form after a specified deadline.

Many SMEs had to import machineries only for government to reverse this policy. This negatively affected so many SMEs in the cocoa industry.

The present high mortality rate of SMEs in Nigeria is awful to contemplate and constitute danger to the entire economic system. It represents serious financial pressure on the nation's economy as well as a waste of valuable resources. The business owner should always consider challenging situations and be prepared to meet them with preplanned strategies Adoyi and Agbo [14]. The survival of SMEs is only possible through a systematic analysis of the problems they are facing and mapping out appropriate strategies of overcoming them, through a proper understanding of the business environment.

For a business to survive in unfriendly environmental conditions it should adopt a strategy that utilizes its strengths to exploit opportunities while avoiding its weaknesses Adeyemi and Badamus [6]. Basil [15], argued that strategic changes might take place in a firm without initial formulations, such decision could be informed by expansion strategy, preference to cash sales policy, innovation strategy, 
change in production techniques, local sourcing or use of alternative materials, backward integration and merger. Thus, any entrepreneur who wants to succeed must identify business opportunities, be creative, visionary, daring, risk taking, courageous and sensitive to changes in the business environment.

\section{Theoretical framework of the study The Theory of Economic Growth}

This research is based on the theory of active learning proposed by Erickson and Pakes [24], which states that a firm explores its economic environment actively and invests to enhance its growth under competitive pressure from both within and outside the firm.

Ikherehon [17], stated that the potential and actual growth changes over time in response to the outcomes of the firm's own investment and those of other actors in the same market. According to this model of learning, owners or managers of SMEs could raise their efficiency through formal education and training that increases their endowments while government may support their activities through the creation of the enabling environment.

Entrepreneurs or managers of SMEs with higher formal education, work experience, training and government assistance would therefore be expected to grow faster than those without these qualities. This implies that SMEs in Nigeria have prospects of experiencing growth and contributing meaningfully to employment generation only when appropriate investments are made into them by all the stakeholders. This could best be achieved by government intervention through the provision of financial assistance, social infrastructures, capacity building of SME operators and favourable taxation policies.

\section{Empirical Review}

Fayemi [25] studied Youth Empowerment and Poverty Alleviation: The Experience in Nigeria (Ogun State). His objectives were; to access and evaluate the effectiveness of policy of poverty alleviation in Ogun State, to access and evaluate the responsiveness of the people to the policy, either positively or negatively, to access and evaluate the achievement and flaws of the policy since its inception in Ogun State. Survey method of research was employed ingathering relevant data for this study. The result of the analysis showed that youth empowerment policy is the best policy for poverty alleviation in Ogun State. The null hypothesis which states that youth empowerment is not the best policy for poverty alleviation is rejected. This implies that youth empowerment policy is the best policy for poverty alleviation among the youths in Ogun State. He concluded by stating that youth should be the first to be reckoned with in any nation aspiring to be great. There is need to empower the youths by giving them functional educational, training and motivation. There is no gain saying that the road to meaningful empowerment is rough, energy sapping and tedious but that notwithstanding, an exemplary youths of today is tomorrow's future leaders. He therefore recommends that creation of resources for the people of Ogun State that will provide investment and infrastructure for better quality of life. Providing vocational skills for array of unemployed, school leavers and graduate of tertiary institutions. Institutionalizing suitable credit delivery system. Providing counseling and extension service on 'start your business' for the youth. There should be collaboration and empowerment among three tiers of government on youth empowerment.

Idris [26] Studied Youth Empowerment and Development Drive - An Invaluable Step to Secure Nigeria's Future Prosperity. His objectives include the following: to discuss the concept of youth empowerment, discuss the various youth empowerment programmes in Nigeria as presented in State Economic Empowerment and Development Strategy (SEEDS) and analyze youth empowerment policies in Nigeria. $\mathrm{He}$ used sample survey for this study and found out that the Youth Empowerment Scheme (Project YES) has succeeded in empowering its beneficiaries in terms of skill acquisition for self-employment. He therefore recommended that governments at all levels should encourage individuals, philanthropists and philanthropic organizations to set up poverty alleviation related NGOs to supplement their efforts in fighting the scourge of poverty in Nigeria. Governments' contribution can be in the form of provision of training centers/workshops and linkages to international donor organizations like the USAID, UNDP, UNESCO, and UNICEF.

\section{Summary of Literature Reviewed}

Fayemi [25] studied Youth Empowerment and Poverty Alleviation: The Experience in Nigeria (Ogun State). He did not discuss the strategies by the state government for youth empowerment. This study is meant to address such issues.

Idris [26] Studied Youth Empowerment and Development Drive - An Invaluable Step to Secure Nigeria's Future Prosperity. He failed to highlight some of the challenges encountered by the government in youth empowerment and this study is been designed to highlight these challenges as well as recommend appropriate solutions to circumvent these challenges.

\section{RESEARCH DESIGN AND METHODOLOGY Research Design}

This study is a descriptive type. According to Orji [27] descriptive research is concerned with the collection, presentation, analysis and interpretation of data for the purpose of describing vividly existing conditions, prevailing practical beliefs, attitudes and ongoing processes. 
Area of Study

Ezeagu is a Local Government Area of Enugu State, Nigeria. Its headquarters are in the town of Aguobu-Owa.

It has an area of $633 \mathrm{~km}^{2}$ and a population of 169,718 at the 2006 census Ezeagu Local Government Area is endowed with natural and cultural tourism resources located all over the community, having the highest concentration in Ihuezi Obunaofia Ndionu community, which when harnessed can produce a distinctive tourism industry capable of generating income and raising the living standard of the people.

The Local Government is under Enugu State West Agricultural zones in Enugu State namely Enugu East Zone, Enugu West Zone and Enugu North Zone, Enugu West Zone comprises of Udi, Ezeagu. Oji-River, Awgu, Ani-nri.

Ezeagu Local Government Area is endowed with natural and cultural tourism resources located all over the community, having the highest concentration in Ihuezi Obunaofia Ndionu community, which when harnessed can produce a distinctive tourism industry capable of generating income and raising the living standard of the people.

The local government under study is bounded in the west by Oji-River, in the North by Igbo-Etiti in the south by Awka Local Government Area of Anambra State and to the East by Udi Local Government Area. It falls within the tropical climate of equatorial region. Thus the main temperature ranges from $100 \mathrm{c}$ to $200 \mathrm{c}$ with a rainfall of $35 \mathrm{~cm}$ to $165 \mathrm{~cm}$ per annum, having peak period in July and August Ofomata [28]. It has a vegetation zone of derived savannah, characterized by woody with rich and vast agricultural resources. The main occupation of the inhabitants is farming with few traders and government

\section{Population of Study}

The population of study covers all the small scale firms owned by the youths located in Ezeagu Local Government Area of Enugu State. The total population of the SMEs is 57 with 1308 employee/staff.

\section{Determination of Sample Size}

In order to get a representation of the entire population, the Taro Yamani statistical formula was employed. According to Taro Yamene [29] the formula is stated as follows:

$$
\mathrm{n}=\frac{\mathrm{N}}{1+\mathrm{N}(\mathrm{e})^{2}}
$$

Where,

$$
\begin{aligned}
& n=\text { represents the sample size } \\
& N=\text { represents the population } \\
& E=\text { represents the margin of error } \\
& I=\text { constant }
\end{aligned}
$$

For the purpose of this study, $\mathrm{N}$ will be equal to 1362 , e will be assumed to be $5 \%$ will be

Therefore the sample size for this research work

$$
\begin{aligned}
\mathrm{n} & =\frac{1308}{1+1308(0.05)^{2}} \\
& =\frac{1308}{1+1308(0.0025)} \\
& =\frac{1308}{1+3.27} \\
& =\frac{1308}{4.27} \\
\mathrm{n} & =306
\end{aligned}
$$

Table-1: Questionnaire Distribution and Returns

\begin{tabular}{|l|l|l|l|l|}
\hline \multicolumn{1}{|c|}{ OPTIONS } & No. Distributed & No. Returned & No. not returned & Percentage (\%) \\
\hline Entrepreneur owners & 57 & 55 & 2 & $18 \%$ \\
\hline Employees & 99 & 93 & 6 & $30 \%$ \\
\hline Staff & 150 & 142 & 8 & $46 \%$ \\
\hline Total & 306 & 290 & 16 & $94 \%$ \\
\hline
\end{tabular}

Source: Field Survey, 2018

The above table shows that a total of 57 copies of the questionnaire were distributed to the entrepreneur owners, 55 copies were returned while 2 copies were lost representing a return rate of $18 \%$. 99 copies were distributed to the employees and 93 copies were returned while 6 copies were lost representing a return rate of $30 \%$. While out of the 150 copies of questionnaire distributed to the staff, 142 copies were returned and 8 copies were lost representing a return rate of $46 \%$. Therefore, the total return rate is $94 \%$.

\section{Method of Data Analysis}

In treating and analyzing of data collected extensive use of tabular and percentage will be paramount. The data collected will be presented in table and analyzed with percentage. The hypotheses will be analyzed by the use of Chi - Square formular.

The formular is shown below:

$$
\mathrm{X}^{2}=\frac{\Sigma(\mathrm{o}-\mathrm{e})^{2}}{\mathrm{e}}
$$


P. C. Okonkwo et al; Saudi J Bus Manag Stud, Sep 2019; 4(9): 774-786

Where,

$\mathrm{X}^{2}=\mathrm{Chi}-$ Square

$\mathrm{O}=$ Observed frequency

$\mathrm{E}=$ Expected frequency

\section{Data Presentation and Analysis}

Data Presentation

The presentation of data collected means the way of arranging the different forms of data obtained through various data collecting techniques to enable the researcher perform analysis and exact new meaning from it. The data collected will be presented in simple table. The data analyses were based on the answer to the key questions received from the various departments. The key questions in the questionnaires will be analyzed by the use of simple percentage.

Table-2: Questionnaire Distribution and Returns

\begin{tabular}{|l|l|l|l|l|}
\hline OPTIONS & No. Distributed & No. Returned & No. not Returned & $\begin{array}{l}\text { Percentage Returned } \\
(\mathbf{\%})\end{array}$ \\
\hline Entrepreneur owners & 57 & 55 & 2 & 18 \\
\hline Employees & 99 & 93 & 6 & 30 \\
\hline Staff & 150 & 142 & 8 & 46 \\
\hline Total & 306 & 290 & 16 & 94 \\
\hline
\end{tabular}

Source: Field Survey, 2018

The above table shows that a total of 57 copies of the questionnaire were distributed to the entrepreneur owners, 55 copies were returned while 2 copies were lost representing a return rate of $18 \% .99$ copies were distributed to the employees and 93 copies were returned while 6 copies were lost representing a return rate of $30 \%$. While out of the 150 copies of questionnaire distributed to the staff, 142 copies were returned and 8 copies were lost representing a return rate of $46 \%$. Therefore, the total return rate is $94 \%$.

\section{Test of Hypotheses}

The hypotheses will be tested using the chisquare formula stated below:

$$
\mathrm{X}^{2}=\frac{\sum(0-\mathrm{e})^{2}}{\mathrm{e}}
$$

Where,

$\mathrm{X}^{2}=$ calculated chi-square

$0=$ observed frequency

$$
\mathrm{E}=\text { expected frequency }
$$$$
\Sigma=\text { summation }
$$

The expected frequency (e) is calculated by adding all the observed frequency (0) and dividing by the number of observations.

Decision Rule: If the calculated chi-square value $\left(\mathrm{X}^{2}\right)$ is greater than or equal to the table value at 0.05 level of significance, the alternate hypothesis $\left(\mathrm{H}_{1}\right)$ is accepted, but if the calculated chi-square value is less than the table value, the null hypothesis $\left(\mathrm{H}_{0}\right)$ is accepted.

\section{Hypothesis one:}

$\mathrm{H}_{\mathrm{O}}$ : Small and medium scale enterprises do not play significant roles in youth empowerment in Enugu State.

$\mathrm{H}_{\mathrm{I}}$ : Small and medium scale enterprises play significant roles in youth empowerment in Enugu State.

\begin{tabular}{|c|c|c|c|c|c|}
\hline Variables & $\mathbf{O}$ & $\mathbf{E}$ & $\mathbf{0}-\mathbf{E}$ & $\begin{array}{ll}\left(\mathrm{O}^{2}\right. & - \\
\mathrm{E})^{2}\end{array}$ & $\frac{(0}{\frac{E)^{2}}{E}}$ \\
\hline Entrepreneurship promotion & 120 & 72.5 & 475 & 2256.25 & 31.12 \\
\hline Provision of employment opportunities & 80 & 72.5 & 7.5 & 56.25 & 0.78 \\
\hline $\begin{array}{l}\text { Mobilization of savings and financial resources for } \\
\text { productive enterprise activities }\end{array}$ & 60 & 72.5 & - & 156.25 & 2.15 \\
\hline $\begin{array}{l}\text { Equitable growth across regions and between men and } \\
\text { women }\end{array}$ & 30 & 72.5 & -42.5 & 1806.25 & 24.91 \\
\hline Total & 290 & 290 & & & 58.96 \\
\hline
\end{tabular}

Data from table 4.8 was used to test the hypothesis

The calculated chi-square value $=58.96$

$\mathrm{Df}=(\mathrm{K}-1)(4-1)=3$

Table value at 0.05 of significance and 4 degree of freedom $(\mathrm{Df})=7.3777$

Decision: Since the calculated chi-square $\left(X^{2}\right)$ value
(58.96) is greater than table value (7.3777), we reject the null hypothesis (Ho) and accept the alternate hypothesis $\left(\mathrm{H}_{1}\right)$ which states that small and medium scale enterprises play significant roles in youth empowerment in Enugu State. 
P. C. Okonkwo et al; Saudi J Bus Manag Stud, Sep 2019; 4(9): 774-786

Hypothesis Two

$\mathrm{H}_{\mathrm{O}}$ : Capital has not affected the role of small and medium scale enterprises in youth empowerment in Enugu State.
$\mathrm{H}_{\mathrm{I}}$ : Capital has affected the role of small and medium scale enterprises in youth empowerment in Enugu State.

Data from table 4.9 was used to test the hypothesis

\begin{tabular}{|l|l|l|l|l|l|}
\hline Variables & $\mathbf{O}$ & $\mathbf{E}$ & $\mathbf{0}-\mathbf{E}$ & $(\mathbf{O}-\mathbf{E})^{2}$ & $\frac{(\mathbf{0}-\mathbf{E})^{2}}{\mathbf{E}}$ \\
\hline Provision of infrastructural development & 129 & 72.5 & 56.5 & 3192.25 & 44.03 \\
\hline Promotion of small and medium scale enterprises through its policies & 57 & 72.5 & -15.5 & 240.25 & 3.31 \\
\hline Provision of capital and loans to small and medium scale business owners & 80 & 72.5 & 7.5 & 56.25 & 0.78 \\
\hline Provision of skill acquisition centers in diverse areas & 24 & 72.5 & -48.5 & 2352.25 & 32.44 \\
\hline Total & $\mathbf{2 9 0}$ & $\mathbf{2 9 0}$ & & & $\mathbf{8 0 . 5 6}$ \\
\hline
\end{tabular}

The calculated chi-square value $=80.56$

$\mathrm{Df}=(\mathrm{K}-1)(4-1)=3$

Table value at 0.05 of significance and 4 degree of freedom $(\mathrm{Df})=7.3777$

Decision: Since the calculated chi-square $\left(X^{2}\right)$ value (80.56) is greater than table value (7.3777), we reject the null hypothesis (Ho) and accept the alternate hypothesis $\left(\mathrm{H}_{1}\right)$ which states that capital has affected the role of small and medium scale enterprises in youth empowerment in Enugu State.

\section{Summary of Findings}

The summary of findings made for this study includes the following:

The study found out that $41 \%$ of the respondents are of the view that one of the roles of small and medium scale enterprises in youth empowerment in Enugu State is entrepreneurship promotion, $28 \%$ said it is provision of employment opportunities, $21 \%$ said it is mobilization of savings and financial resources for productive enterprise activities while $13 \%$ said it is equitable growth across regions and between men and women. Therefore, the roles of small and medium scale enterprises in youth empowerment in Enugu State are entrepreneurship promotion, provision of employment opportunities, mobilization of savings and financial resources for productive enterprise activitiesand equitable growth across regions and between men and women.

The study discovered that $44 \%$ of the respondents are of the opinion that one of the contributions of government in SME development is provision of infrastructural development, $20 \%$ said it ispromotion of small and medium scale enterprises through its policies, $28 \%$ said provision of capital and loans to small and medium scale business owners while $8 \%$ said provision of skill acquisition centers in diverse areas. Therefore, the contributions of government in SME development are provision of infrastructural development, promotion of small and medium scale enterprises through its policies, provision of capital and loans to small and medium scale business owners andprovision of skill acquisition centers in diverse areas.
The researcher found out that $41 \%$ of the respondents are of the view that capital formation has affected the role of small and medium scale enterprises in youth empowerment in Enugu State to a very great extent, $31 \%$ said to a great extent, $22 \%$ said to an extent while $13 \%$ said not at all. Therefore, capital formation has affected the role of small and medium scale enterprises in youth empowerment in Enugu State to a very great extent.

The study found out that $27 \%$ of the respondents are of the view that one of the challenges militating against the efforts of small and medium scale enterprises in youth empowerment in Enugu State is financial problems, $20 \%$ said management problems, $42 \%$ said infrastructure problems while $11 \%$ socio cultural problems. Therefore, the challenges militating against the efforts of small and medium scale enterprises in youth empowerment in Enugu State are financial problems, management problems, infrastructure problems and socio cultural problems.

\section{CONCLUSION}

The roles of small and medium scale enterprises in youth empowerment in Enugu State are entrepreneurship promotion, provision of employment opportunities, mobilization of savings and financial resources for productive enterprise activitiesand equitable growth across regions and between men and women.

The contributions of government in SME development are provision of infrastructural development, promotion of small and medium scale enterprises through its policies, provision of capital and loans to small and medium scale business owners and provision of skill acquisition centers in diverse areas.

Capital formation has affected the role of small and medium scale enterprises in youth empowerment in Enugu State to a very great extent.

The challenges militating against the efforts of small and medium scale enterprises in youth empowerment in Enugu State are financial problems, 
management problems, infrastructure problems and socio cultural problems.

The measures to circumvent such problems are provision of infrastructural facilities, accessibility of credit facilitiesand establishment of entrepreneurial development centers across the country to encourage and build capacity for business-minded youths.

\section{RECOMMENDATIONS}

In view of the findings so far, the recommendations are that:

- Government at all levels in Nigeria should be encouraged to float Microfinance institutions in order to enable SMEs access enough funds for their businesses. This will enable the poor in their areas to have access to credit without which strives for financial inclusion and poverty eradication will not be realized.

- The central Bank of Nigeria (CBN) should hasten up its proposal to introduce financial literacy in school's curriculum. The ability of SMEs to keep appropriate and up to date records are what banks require for extension of their credits to individuals and groups.

- The CBN as the apex financial institution should establish entrepreneurial development centers across the country to encourage and build capacity for business-minded youths.

- Government should increase its efforts towards the provision of infrastructure such as electricity, and transport without which SMEs cannot thrive efficiently.

- Government in Nigeria should establish and empower more agencies to assist the existing ones such as the EFCC and ICPC to tackle bribery and corruption headlong, as businesses cannot thrive in an environment where bribery and corruption thrive.

- The youths should be encouraged form the habit of saving and investing as little as they can without waiting for government always.

\section{REFERENCES}

1. Adenikinju A. Analysis of the Cost of Infrastructure Failures in a Developing Economy. Onitsha: African Fep Publishers. 2010.

2. Akpan GE, Ekong CN. Youth Empowerment for Sustainable Development. Uyo: Minder International. 2012.

3. Ekong G. Youth empowerment for sustainable development. Uyo: Minder International. 2009.

4. Seavoy RE. Subsistence and economic development. Westport: Praeger Publishers. 2011.

5. Ubon E. Entrepreneurship, Small and Medium Enterprises: Theory, Practices and Policies, Lagos: Sendina Ltd. 2003.

6. Adeyemi SL, Badamus AL. An Empirical Study of Small Scale Financing in Nigeria. Journal of Unilorin Business School. 2011; 11(9).
7. World Bank. Nigeria's Poverty in the Midst of Plenty: The challenge of Growth. World Bank Papers Washington D.C. 2006.

8. Hassan O. The contribution of various Schemes to the growth of SMEs in Nigeria, Abuja: Habib Nigeria Limited. 2008.

9. Ike D. Poverty eradication in Nigeria: The way forward, Enugu: Chukwudi and Sons Nigeria Limited. 2006.

10. Inegbenobor U. Equity investment in Small Scale Businesses. Onitsha: African Fep Publishers. 2011.

11. Jimodu A. Small and Medium Scale Enterprises and the Nigerian Economy, Ibadan: Akindele and co. Ltd. 2008.

12. Kayode S. The development of Small and Medium Scale Enterprises in Nigeria: Lagos, Oshopy Press. 2010.

13. Olagunju YA. Entrepreneurship and Small Scale Business Enterprises Development in Nigeria, Ibadan, University press plc. 2009.

14. Adoyi PO, Agbo JC. An Assessment of the Contribution of Small Business Firms to the Development of Benue State. Journal of Research in National Development. 2009;7(1):1-2.

15. Basil ANO. Small and Medium Enterprises (SMES) In Nigeria: Problems and Prospects. Enugu: Abic Books and Equipment. 2010.

16. Ekezie C. Breakdown of Business Ventures in Nigeria. Lagos: Concept Publishers Limited. 2008.

17. Ikherehon IG. The Practice business guide for the entrepreneur in Africa. Lagos: Pathead Enterprises. 2009.

18. Ireghan C. The Place of Small and Medium Scale Business in the development of a nation State. Lagos: Kaycee Publishers. 2011.

19. Iromaka C. Entrepreneurship in small business firms. Ikeja: G-Mag. Investments Ltd, (Educational Publishers). 2006.

20. Izedomi A. Principles of Management, Benin: Alfred-Joe Publishers. 2011.

21. Akingunola RO. Small and medium scale enterprises and economic growth in Nigeria: An assessment of financing options. Pakistan Journal of Business and Economic Review. 2011;2(1).

22. Sanusi L. An Empirical evaluation of Small and Medium Enterprises equity Investment Scheme in Nigeria. Journal of Accounting and taxation, 2013; 5(3).

23. Safiriyu AM, Njogo BO. Impact of Small and Medium Scale Enterprises in Lagos State. Kuwait Chapter of Arabian journal of Business and Management Review, 2012; 11(1).

24. Erickson T, Pakes A. An experimental component index for the CPI: from annual computer data to monthly data on other goods. American Economic Review. 2011 Aug;101(5):1707-38.

25. Fayemi AK. A critique of consensual democracy and human rights in Kwasi Wiredu's Philosophy. Lumina: An Interdisciplinary Research and scholarly Journal. 2010 Jun 22;21(1):1-3. 
26. Wahidin S, Idris A, Shaleh SR. The influence of light intensity and photoperiod on the growth and lipid content of microalgae Nannochloropsis sp. Bioresource technology. 2013 Feb 1;129:7-11.

27. Orji NG, Martinez A, Dixson RG, Allgair J. Progress on implementation of a CD-AFM-based reference measurement system. InMetrology, Inspection, and Process Control for
Microlithography XX 2006 Mar 24 (Vol. 6152, p. 615200). International Society for Optics and Photonics.

28. Ofomata GE, editor. Nigeria in maps: Eastern states. Ethiope publishing house; 1975.

29. Yamane T. Statistics: An Introductory Analysis. Appendix Tables. App. Harper \& Row; 1964. 